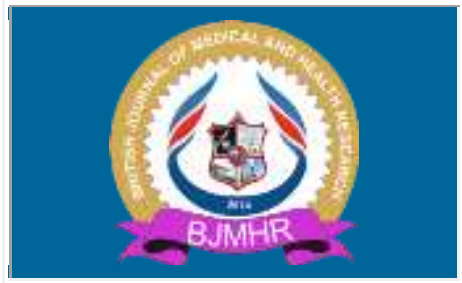

\title{
BJMHR
}

British Journal of Medical and Health Research Journal home page: www.bjmhr.com

\section{Protective Effect of L-Carnitine Against Reproductive Toxicity of Monosodium Glutamate In Male Albino Mice}

Ahmad A. Kandeel*, Abd-El-karim M. Abd-Lateif, Wessam S. Tawfik, Khalid H. Zaghloul

Zoology Department, Faculty of Science, Fayoum University, Egypt.

\begin{abstract}
Monosodium glutamate (MSG) is commonly used as food enhancer which causes a wide range of toxic effects including reduced male fertility. This study was carried out to investigate the protective effect of L-carnitine against monosodium glutamate (MSG)induced testicular toxicity in adult male mice. Sixty adult male albino mice (age 10 weeks) were used in the present study and divided into six groups. Group I used as control group (10 mice). Group II (10 mice) received $150 \mathrm{mg} / \mathrm{kg} /$ day L-carnitine. Group III\& IV (10 mice each) was received 0.3 and $0.6 \mathrm{mg} \mathrm{MSG/g}$ body weight. Group V and VI (10 mice each) received 0.3 and $0.6 \mathrm{mg} \mathrm{MSG} / \mathrm{g}$ body with $150 \mathrm{mg}$ L-carnitine/kg body weight. All animals were treated orally by gastric intubation for 35 days. Reproductive performance, gonadosomatic index (GSI), sperm count, motility, and morphology as well as comet assay were studied. The study demonstrated that L-carnitine ameliorated MSG alterations in testicular weight, sperm count, sperm motility, and sperm morphology together with DNA degradation. This study indicated that the treatment of mice with L-carnitine enhances MSG reproductive toxicity by improving sperm quality and DNA status.
\end{abstract}

Keywords: Glutamate, Mice, Sperm, Reproductive Toxicity, L-carnitine. 


\section{INTRODUCTION}

Monosodium L- glutamate (MSG) is the most common food additive used as a flavor enhancer. The median lethal dose $\left(\mathrm{LD}_{50}\right)$ in rats and mice is $15.000-18.000 \mathrm{mg} / \mathrm{kg}$ body weight ${ }^{(1)}$. Although MSG has proven its value as an enhancer of flavor, different studies have hinted at possible toxic effects related to this popular food-additive. These toxic effects include CNS disorder, obesity, disruptions in adipose tissue physiology, hepatic damage, CRS and reproductive malfunctions $\left({ }^{2}\right)$. Results from both animal and human data have demonstrated that administration of even the lowest dose of MSG has toxic effects. The average intake of MSG per day is estimated to be $0.3-1.0 \mathrm{~g}\left({ }^{3}\right)$. MSG could cause symptoms such as headaches, weakness, sweating, dizziness, flushing and numbness. Moreover to these MSG symptom complex, consumption of MSG has been unproven to cause or intensify numerous conditions, including ventricular arrhythmia, asthma, atopic dermatitis, urticaria, neuropathy and abdominal discomfort $\left({ }^{4}\right)$. Many authors revealed that MSG intake causes a disrupted energy balance by increasing the palatability of food and disturbing the leptinmediated hypothalamus signalling cascade, potentially leading to obesity $\left({ }^{5,6}\right)$. MSG at doses of 0.6 and $1.6 \mathrm{mg} / \mathrm{g}$ of body weight may cause an adverse effect on the hepatic and renal functions in rats $\left(^{7}\right)$. MSG has a testicular toxic effect by causing a significant oligozoospermia and increase sperm abnormality in a dose-dependent manner in male Wistar rats $\left({ }^{8}\right)$. It has been associated in male infertility by causing testicular hemorrhage, degeneration and alternation of sperm cell count and morphology $\left({ }^{9}\right)$. Igwebuike et al. $\left({ }^{10}\right)$ used a gavage needle to administer MSG solution for 6 weeks to male albino rats and reported a disruption of hypothalamic-pituitary-testes regulatory axis, as well as a lowered serum testosterone. Moreover El-Sawy et al. $\left({ }^{11}\right)$ reported that rats were administered orally MSG ( $2 \mathrm{~g} / \mathrm{kg} /$ day) for 4 weeks showed reduced serum levels of testosterone, luteinizing hormone (LH), sperm profiles and testicular antioxidant activities. At the molecular levels, MSG down-regulated the mRNA expression of steroidogenesis related genes and receptors of androgen, LH and follicle stimulating hormone. MSG induced testicular apoptosis.

Antioxidants are naturally found in semen include vitamins $\mathrm{E}$ and $\mathrm{C}$, folate, zinc, selenium, carnitine and carotenoids. These antioxidants act as free radical scavengers that help to overcome $\operatorname{ROS}\left({ }^{12}\right)$. L-Carnitine is an amino acid; approximately $25 \%$ is synthesized from lysine and methionine and naturally is produced in the body and is a water-soluble antioxidant that mostly derived from the human diet. Carnitine at extracellular and intracellular levels may play a significant role in sperm energy metabolism, and provide the primary fuel for sperm motility during epididymal passage $\left({ }^{13}\right)$. The healthy epididymides contains Carnitines in both free and acetylated forms for use of spermatozoa via 
mitochondrial $\beta$-oxidation of long chain fatty acids, as a main transferring system of the acyl to the mitochondrial $\mathrm{CoA}$, and by decreasing fatty acid oxidation restore the phospholipid composition of mitochondrial membranes $\left({ }^{14,15}\right)$.

L-carnitine is essential for the $\beta$-oxidation of fatty acids in mitochondria to generate ATP $\left({ }^{16,17}\right)$. It was found to possess strong antioxidant, anti-inflammatory and antiapoptotic properties $\left({ }^{18,19,20}\right)$. L-carnitine can protect from hepatotoxic, neurotoxic, renal impairment and genotoxic effects. Biochemically and histopathologically with a corresponding reduction of oxidative stress $\left({ }^{21}\right)$. L-carnitine has also been shown to play an important role in the control of the male reproductive system and normal function of the testis, where it is highly concentrated in the male reproductive system, especially in the epididymis $\left({ }^{22}\right)$. It acts on male gamete maturation and seems to have a key role in: providing readily available energy for sperm motility $\left({ }^{22,23}\right)$, sperm DNA repair $\left({ }^{24}\right)$, germ cell recovery $\left({ }^{25}\right)$, protecting sperms against oxidative damage, reducing apoptosis of spermatogenic cells and inhibiting sperms aggregation $\left({ }^{26}\right)$. Nutritional supplementation with L-carnitine improves sperm quality and/or quantity in the testis of rat $\left({ }^{27}\right)$ and mice $\left({ }^{28}\right)$ exposed to X-ray irradiation. Furthermore, it has been shown that L-carnitine has protective effects on the testis of atherosclerotic rats $\left({ }^{29}\right)$. In addition, L-carnitine has a protective effect on di (2-ethylhexyl) Phthalate $\left({ }^{30}\right)$, ischaemiareperfusion $\left({ }^{20}\right)$ and etoposide $\left({ }^{31}\right)$ induced testis injury in rats. So the aim of the present study was to go more through the toxic effects of two sublethal doses of monosodium glutamate on semen quality and determine the possible reversibility of these effects using L-carnitine as antioxidant.

\section{MATERIALS AND METHOD}

\section{Chemicals}

Materials used in this research were Monosodium glutamate (MSG) was obtained from FLUKA chemical Co. (USA) and it was liquefied in distilled water. L-Carnitine was purchased from MEPACOMEDI FOOD the L-carnitine powder which obtained from capsules (each one contain 350mg L-carnitine) was dissolved in distilled water solution .

\section{Experimental animals}

Experimental animals used in this research were male mice (Mus musculus) approximately aged 7-8 weeks with average weight of 25-30 g animals were derived from Vacsera, Egypt (www.mohp.gov.eg/vacsera). Mice were acclimated to lab environment for 10 days in under normal condition of lightening and ventilation. Animals were housed in cages, and given the standard diet and water ad-libitum the study period.

\section{Experimental Design}

Sixty mature male Mus musculus mice weighting $28 \pm 2 \mathrm{~g}$ were used in the present study. 
Mice were randomly assigned to 6 groups of 10 animals each. Animals of different studied groups were exposed to oral doses of MSG and/or L-carnitine as follows:

Group (1): Control group, ten mice were orally administrated with $0.2 \mathrm{ml}$ of distilled water.

Group (2): Mice were orally administered with oral daily dose $150 \mathrm{mg} / \mathrm{kg}$ of L- carnitine

Group (3): Mice were orally administered with a daily dose of 1/60 LD 50 of MSG (low dose, $0.3 \mathrm{mg}$ MSG /g body weight)

Group (4): Mice were orally administered with a daily dose of 1/30 LD50 of MSG (high dose, $0.6 \mathrm{mg} \mathrm{MSG/g}$ body weight)

Group (5): Mice were orally administered daily with low dose of MSG concurrent with oral dose $150 \mathrm{mg} / \mathrm{kg}$ L-carnitine

Group (6): Mice were orally administered daily with high dose of MSG concurrent with oral dose of $150 \mathrm{mg} / \mathrm{kg}$ of L-carnitine

Animals of all control and treated groups were orally treated for 35 days.

\section{Reproductive performance study}

The fertility and the reproductive performance of both control and treated groups were studied at the end of treatment. Each male of different studied groups was housed with virgin untreated female 1:1 for 10 days (to complete two estrus cycles). Vaginal plugs were observed daily, the day on which the vaginal plug is detected considered as day zero of gestation. The mating index is calculated as the number of males mated and resulting in a vaginal plug over the number of males cohoused with females multiplied by 100 and expressed as the percent. The fertility index is expressed as the number of males which sired a litter over the number of males resulting a vaginal plug multiplied by 100 and expressed as the percent $\left({ }^{32}\right)$.

\section{Evaluation of body $\&$ testes weights and Gonadosomatic index}

During treatment period the body weight of each animal was recorded weekly. The testis was dissected out, cleaned and weighed. The gonadosomatic index (GSI) was calculated by dividing the testis weight by the body weight of each animal and expressed as the percent $\left({ }^{33}\right)$.

\section{Sperm analysis}

The mice were euthanized $24 \mathrm{~h}$ after the last dose. The epididymis was excised and placed in a pre-warmed petri dish containing $0.2 \mathrm{ml}$ of calcium and magnesium free Hank's solution at $37^{\circ} \mathrm{C}$. The tissue was minced with scalpels for approximately $1 \mathrm{~min}$. and placed in $37^{\circ} \mathrm{C}$ incubator for $15 \mathrm{~min}$. The epididymis was processed for sperm motility, viability, count, and sperm anomalies.

\section{Sperm motility:}

The sperm motility was evaluated according to the method of Ekaluo et al. $\left({ }^{34}\right)$, two drops of 
sperm suspension were put on a microscope slide and covered with cover slip and examined under microscope at 40x magnification. The number of progressively motile sperms was recorded and divided by the total number of spermatozoa counted and expressed as percentage .

\section{Sperm viability}

The sperm viability was determined using Eosin-Nigrosin staining technique $\left({ }^{35}\right)$. An equal volume of sperm suspension and Eosin-Nigrosin, stain were mixed; air-dried smears were prepared and examined for each sample. Normal live sperms appeared unstained, while dead ones stained pinkish. The percentage of viable sperms was calculated based on the number of live sperm cells out of the total number of cells examined.

\section{Sperm count:}

Epididymal sperm count was performed according to Ekaluo et al. $\left({ }^{36}\right)$ using the improved Neubauer hemocytometer. Heads of sperms were counted manually under light microscope. Data were expressed as total number of sperm $/ \mathrm{ml}$.

\section{Sperm anomalies:}

The sperm suspension was mixed with $1 \%$ eosin Y solution (10:1) for 30 min. Air-dried smears were prepared for examination of sperm anomalies. Slides were examined for counting the number of sperm with abnormal head, mid-piece and tail for every 200 spermatozoa per each slide. Abnormal sperms was calculated and expressed as the percentage according to Ekaluo et al. $\left({ }^{37}\right)$.

\section{Comet Assay:}

The comet assay was performed to determine DNA damage as designated by Singh et al. $\left({ }^{38}\right)$ with minor modifications. Regular agarose (RA) and low melting point agarose (LMPA) were prepared at $0.75 \%$ and $0.5 \%$ respectively in $\mathrm{Ca}++$ and $\mathrm{Mg}++$ free $\mathrm{PBS}, 110 \mu \mathrm{L}$ of RA were added to fully frosted microscope slides. $75 \mu \mathrm{L}$ of LMPA containing 105 cells were added. Finally, a top layer of $75 \mu \mathrm{L}$ LMPA was added. Slides were immersed in lysis solution for at least $1 \mathrm{~h}$ at $4^{\circ} \mathrm{C}$, and were then left in alkaline buffer for 15 minutes to allow the expression of alkali-labile sites and DNA unwinding. The slides were electrophoresed at $25 \mathrm{~V}$ and $300 \mathrm{~mA}$ for 20 minutes, washed with neutralizing buffer and stained with ethidium bromide $(2 \mathrm{~g} / \mathrm{ml}$ in distilled water). Observations were made at $400 \mathrm{X}$ magnification using a fluorescent microscope (Olympus) equipped with an excitation filter of 515-560 $\mathrm{nm}$ and a barrier filter of $590 \mathrm{~nm}$. When possible, fifty cells per animal were analyzed for DNA migration. The tail length was measured from the trailing edge of the nucleus to the leading edge of the tail, using a calibrated scale in the ocular. The severity of DNA damage was measured comparing comet tail lengths $(\mu \mathrm{m})$ with the diameter of the nucleus of undamaged cells observed in the same field. 


\section{Statistical analysis}

Statistical analysis was performed using the analysis of variance (ANOVA) and Duncan's Multiple Range test to determine differences among treatment means at significant level of $\mathrm{p}<0.05$ and highly significant at $\mathrm{p}<0.01$, Standard errors were also estimated $\left({ }^{39}\right)$. All statistics were run on the computer using SPSS program. All curves were fitted with the computer program office (2007). The paper has been approved by scientific and ethical committee of Zoology Department, Faculty of Science in University of Fayoum 2009.

\section{RESULTS}

Effect of MSG and L-carnitine treatment on body \& testis weights and Gonadosomatic Index

Table (1) demonstrates the effects of MSG on both body and testes weights and gonadosomatic index of male mice. The body weight of high dose only is significantly increased. Meanwhile, the testis weight and gonadosomatic index of all MSG treated groups is significantly reduced when compared with control group $(\mathrm{P}<0.01)$. The reduction in testis weight and gonadosomatic index goes back to normal levels when recovered with L-carnitine treatment. The mice individually treated only with L-carnitine revealed normal testis weight and gonadosomatic index when compared with controls.

Table 1: Final body weight, total testes weights and gonadosomatic index in male albino mice treated with sublethal doses of MSG individually or co-administered with Lcarnitine as antioxidant for 35 days.

\begin{tabular}{llll}
\hline Animal groups & $\begin{array}{l}\text { Final body } \\
\text { weight }(\mathbf{g})\end{array}$ & $\begin{array}{l}\text { Total testes } \\
\text { weight }(\mathbf{g})\end{array}$ & $\begin{array}{l}\text { Gonadosomatic } \\
\text { index \% }\end{array}$ \\
\hline Group 1: Control & $30.80 \pm 1.55$ & $0.25 \pm 0.02$ & $0.82 \pm 0.07$ \\
& $\mathrm{C}$ & $\mathrm{A}$ & $\mathrm{A}$ \\
Group 2: L-carnitine & $29.00 \pm 1.59^{*}$ & $0.23 \pm 0.02$ & $0.81 \pm 0.08$ \\
(150mg/kg/day) & $\mathrm{C}$ & $\mathrm{A}$ & $\mathrm{A}$ \\
Group 3: MSG Low dose & $33.10 \pm 1.37 *$ & $0.22 \pm 0.02 *$ & $0.67 \pm 0.08^{* *}$ \\
(0.3 mg/kg/day) & $\mathrm{B}$ & $\mathrm{C}$ & $\mathrm{B}$ \\
Group 4: MSG High dose & $34.30 \pm 1.33^{* *}$ & $0.20 \pm 0.02 * *$ & $0.57 \pm 0.07 * *$ \\
(0.6 mg/kg/day) & $\mathrm{A}$ & $\mathrm{D}$ & $\mathrm{C}$ \\
Group 5: L-carnitine & $31.60 \pm 1.43$ & $0.25 \pm 0.02$ & $0.81 \pm 0.06$ \\
+ MSG low dose & $\mathrm{C}$ & $\mathrm{A}$ & $\mathrm{A}$ \\
Group 6: L-carnitine & $29.10 \pm 1.17$ & $0.25 \pm 0.02$ & $0.87 \pm 0.07$ \\
+MSG high dose & $\mathrm{C}$ & $\mathrm{A}$ & $\mathrm{A}$ \\
ANOVA & $* *$ & $* *$ & $* *$ \\
\hline
\end{tabular}

Data are represented as mean of 10 samples \pm SE

Means with the same letter for each parameter in the same column are not significantly different, otherwise they do (Duncan multiple range test).

$* * \mathrm{P}<0.01$ Highly Significant.

\section{Reproductive performance}


The reproductive performance of male mice treated with MSG is significantly reduced in mice treated with low and high doses (10\% and $0 \%)$ respectively when compared with $(90 \%)$ in both control and L-carnitine treated group. While co-administration of L-carnitine with both low and high doses of MSG improves the percentage to normal values (90\% and 85\%, respectively). The fertility index is dramatically reduced to $(0 \%)$ in MSG treated groups compared with (100\%) in both control and L-carnitine group. Meanwhile, concurrent administration MSG and L-carnitine recovered the fertility index to nearly the normal values (95\% \& 90\%) as shown in Figure (1).

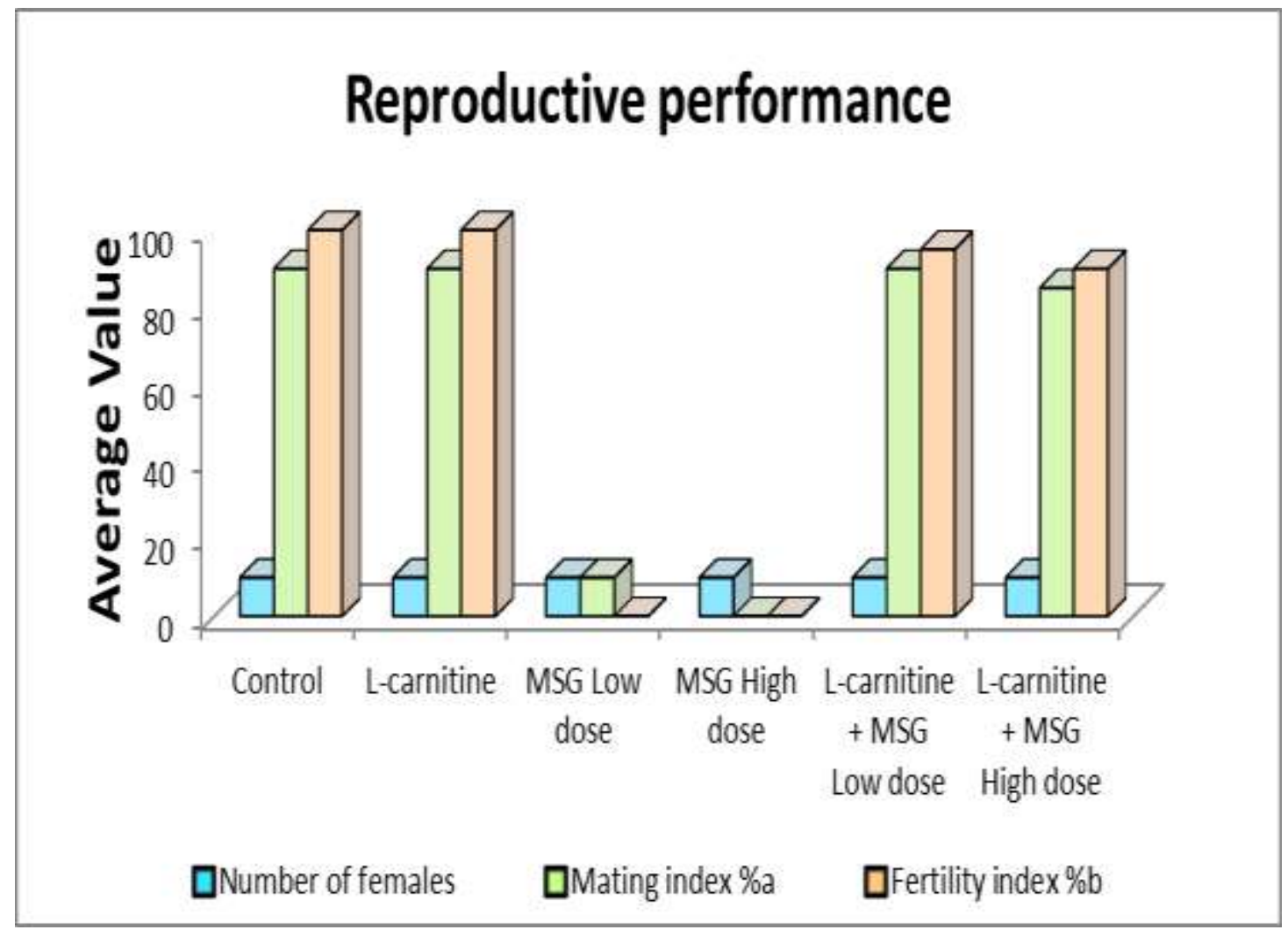

Figure 1: Reproductive performance in male albino mice treated with sublethal doses of MSG individually or co-administered with L-carnitine as antioxidant for 35 days.

Effect of MSG and L-carnitine treatment on sperm count, motility and viability

The data of table (2) demonstrates that the sperm count, motility and viability are significantly reduced in MSG-treated mice. The epididymal sperm count in MSG-treated groups is significantly decreased compared with the control compartment. This reduction is recovered to the normal level via co-administration of L-carnitine $(150 \mathrm{mg} / \mathrm{kg})(\mathrm{p}<0.01)$. The MSG treatment is significantly decline the sperm motility in a dose-dependent manner $(\mathrm{p}<0.01)$. While, concurrent administration of L-carnitine with MSG is significantly enhanced the sperm motility to normal rates $(\mathrm{p}<0.01)$. Also, the percentages of epididymal viable sperms is significantly reduced in MSG-treated mice in comparison with control one. The administration of L-carnitine alone $(150 \mathrm{mg} / \mathrm{kg})$ and in combination with MSG significantly improves the percent of viable sperms compared to control mice $(p<0.01)$. 
Table 2: Assessment of Sperm count $\left(\mathrm{X10}^{6} / \mathrm{mm}^{3}\right)$, motility and viability of male albino mice treated with_sublethal doses of MSG individually or co-administered with Lcarnitine as antioxidant for 35 days.

\begin{tabular}{llll}
\hline Animal groups & Count $\times \mathbf{1 0}$ & $\begin{array}{l}\text { Progressive } \\
\text { Motility \% }\end{array}$ & $\begin{array}{l}\text { Viability } \\
\text { \% }\end{array}$ \\
\hline Group 1: Control & $68.6 \pm 1.1$ & $70.0 \pm 1.1$ & $70.6 \pm 1.2$ \\
& $\mathrm{~A}$ & $\mathrm{~A}$ & $\mathrm{~A}$ \\
Group 2: L-carnitine & $67.5 \pm 1.0$ & $71.2 \pm 0.8$ & $71.7 \pm 0.7$ \\
(150mg/kg/day) & $\mathrm{A}$ & $\mathrm{A}$ & $\mathrm{A}$ \\
Group 3: MSG Low dose & $56.9 \pm 1.1 * *$ & $40.0 \pm 1.2^{* *}$ & $49.8 \pm 1.2^{* *}$ \\
(0.3 mg/kg/day) & $\mathrm{B}$ & $\mathrm{B}$ & $\mathrm{B}$ \\
Group 4: MSG High & $57.9 \pm 1.0^{* *}$ & $30.9 \pm 1.2^{* *}$ & $48.0 \pm 1.1^{* *}$ \\
dose (0.6 mg/kg/day) & $\mathrm{C}$ & $\mathrm{C}$ & $\mathrm{C}$ \\
Group 5: L-carnitine & $67.3 \pm 1.1$ & $69.1 \pm 1.0$ & $69.5 \pm 1.1$ \\
+ MSG low dose & $\mathrm{A}$ & $\mathrm{A}$ & $\mathrm{A}$ \\
Group 6: L-carnitine & $67.2 \pm 1.2$ & $69.0 \pm 1.0$ & $69.7 \pm 1.0$ \\
+MSG high dose & $\mathrm{A}$ & $\mathrm{A}$ & $\mathrm{A}$ \\
ANOVA & $* *$ & $* *$ & $* *$ \\
\hline
\end{tabular}

Data are represented as mean of 10 samples \pm SE

Means with the same letter for each parameter in the same column are not significantly different, otherwise they do (Duncan multiple range test).

$* * \mathrm{P}<0.01$ Highly Significant.

\section{Evaluation of sperm anomalies}

The sperm abnormalities listed in (Table3) showed a highly significant increase in the incidence percent of sperms anomaly $(\mathrm{P}<0.01)$ in all the MSG groups compared with the corresponding control and L-carnitine treated groups. On the other hand, treated groups with MSG combined with L-carnitine showed a significant increase in number of normal sperms and decreased incidence of sperm abnormality. 
Table 3: Types of the recorded sperm abnormalities in male albino mice treated with low and high doses of MSG individually or co-administered with $\mathrm{L}$ - carnitine as antioxidant for 35 days.

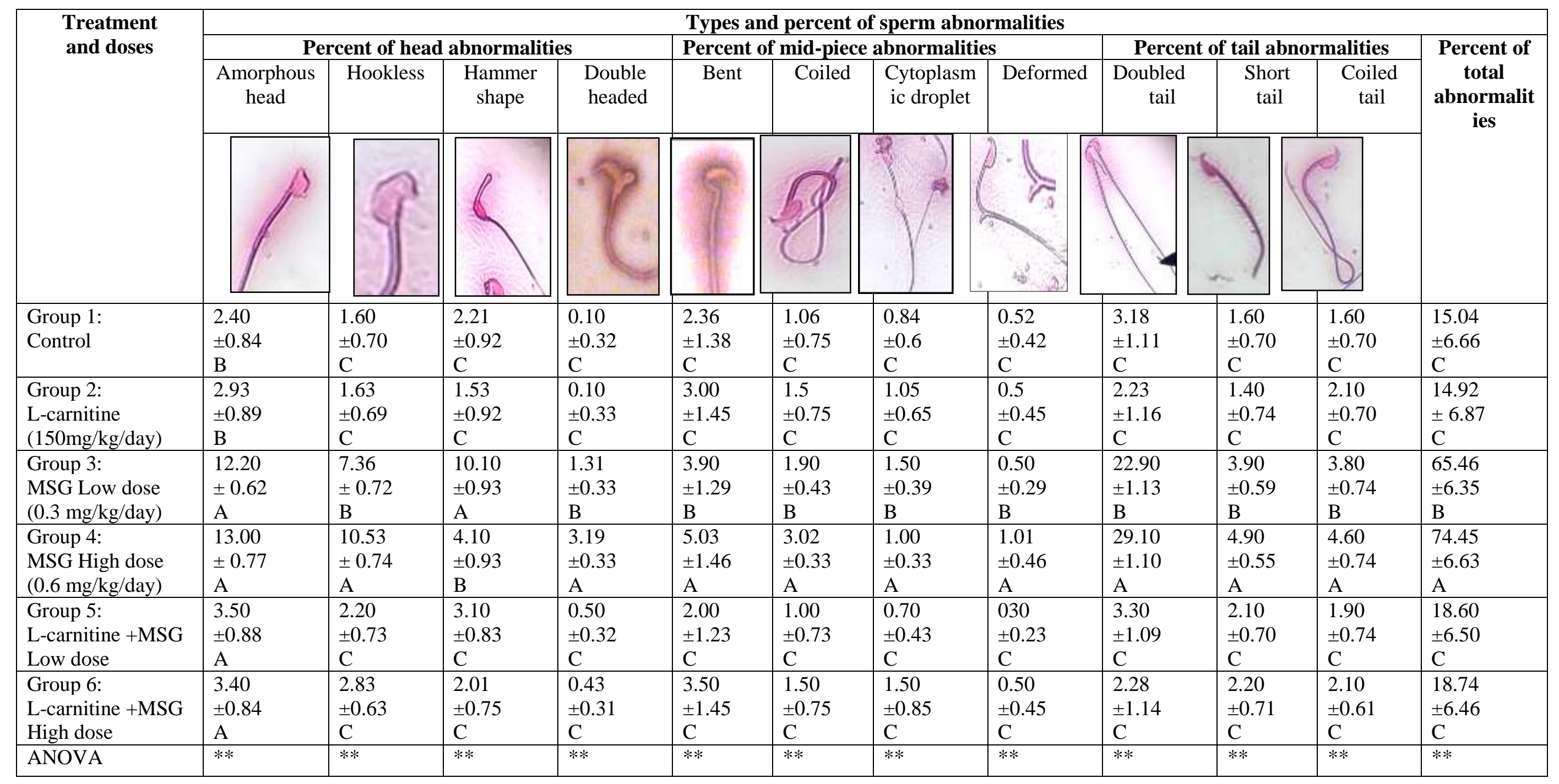


Data are represented as mean of 10 samples \pm SE. Means with the same letter for each parameter in the same column are not significantly different, otherwise they do (Duncan multiple range test). $* * \mathrm{P}<0.01$ Highly Significant

\section{Comet assay}

In mice testes of all groups, the quantitative and qualitative extent of DNA damage in the cells was measured by the length of DNA migration and the percent of migrated DNA. All comets were quantified by three comet parameters (percent of tail DNA, tail moment and the olive tail moment). Comet assay revealed that, MSG induced statistically significant $(\mathrm{P}<0.05)$ and highly significant $(\mathrm{P}<0.01)$ increase in the average of the comet percent from $8.6 \pm 0.39$ and $8.39 \pm 0.03$ in control and L-carnitine groups to $15.9 \pm 0.41$ and $17 \pm 0.39$ in low and high doses of MSG treated groups. While in groups treated with L-carnitine and low and high doses of MSG showed nearly normal comet assay (8.96 \pm 0.36 and 9.41 \pm 0.37 ). Tail length was highly significant increase in low and high MSG treated groups $(3.87 \pm 0.41$ and $5.5 \pm 0.41)$ than control and L-carnitine treated groups (2.72 \pm 0.20 and 2.54 \pm 0.41$)$; while the coadministered groups (L-carnitine with low and high doses of MSG) showed non-significant changes in comparison with the control $(2.64 \pm 0.41$ and $2.92 \pm 0.41)$. The percent of DNA in comet tail showed highly significant increase in low and high doses of MSG treated groups (30.73 \pm 0.37 and $33.10 \pm 0.41)$ comparing with the control (17.03 \pm 1.02$)$ and L-carnitine group (17.42 \pm 0.29 ), however the L-carnitine with low and high doses of MSG showed nonsignificant change (17.96 \pm 0.4 and $18.36 \pm 0.4)$ in comparison with control group $(17.03 \pm 1.02)$. Tail moment showed highly significant increase in low and high doses of MSG treated groups $(1.4 \pm 0.41$ and $1.52 \pm 0.41)$ compared with the control $(0.77 \pm 0.13)$ and L-carnitine $(0.87 \pm 0.41)$ groups while the L-carnitine with low and high doses of MSG treated groups showed non-significant change $(0.83 \pm 0.4$ and $0.9 \pm 0.4)$ in comparison with the control group (0.77 \pm 0.13$)$ (Table 4 and Fig. 2).

Table 4: Comet assay in the sperm of male albino mice treated with sublethal doses of MSG individually or co-administered with L-carnitine as antioxidant for 35 days.

\begin{tabular}{lllll}
\hline Animal groups & $\begin{array}{l}\text { Comet } \\
\text { \% }\end{array}$ & $\begin{array}{l}\text { Tail } \\
\text { length }\end{array}$ & $\begin{array}{l}\text { \% } \\
\text { DNA in tail }\end{array}$ & $\begin{array}{l}\text { Tail } \\
\text { moment }\end{array}$ \\
\hline Group 1: Control & $8.6 \pm 0.39 \mathrm{C}$ & $2.72 \pm 0.20 \mathrm{C}$ & $17.03 \pm 1.02 \mathrm{C}$ & $0.77 \pm 0.13 \mathrm{C}$ \\
Group 2: & $8.39 \pm 0.03$ & $2.54 \pm 0.41$ & $17.42 \pm 0.29$ & $0.87 \pm 0.41$ \\
L-carnitine(150mg/kg/day) & $\mathrm{C}$ & $\mathrm{C}$ & $\mathrm{C}$ & $\mathrm{C}$ \\
Group 3: & $15.9 \pm 0.41$ & $3.87 \pm 0.41$ & $30.73 \pm 0.37$ & $1.4 \pm 0.41$ \\
MSG Low dose(0.3 mg/kg/day) & $\mathrm{B}$ & $\mathrm{B}$ & $\mathrm{B}$ & $\mathrm{B}$ \\
Group 4: & $17 \pm 0.39$ & $5.5 \pm 0.41$ & $33.1 \pm 0.41$ & $1.52 \pm 0.41$ \\
MSG High dose(0.6 mg/kg/day) & $\mathrm{A}$ & $\mathrm{A}$ & $\mathrm{A}$ & $\mathrm{A}$ \\
Group 5: & $8.96 \pm 0.36$ & $2.64 \pm 0.41$ & $17.96 \pm 0.40$ & $0.83 \pm 0.40$ \\
L-carnitine+ MSG low dose & $\mathrm{C}$ & $\mathrm{C}$ & $\mathrm{C}$ & $\mathrm{C}$ \\
Group 6: & $9.41 \pm 0.37$ & $2.92 \pm 0.41$ & $18.36 \pm 0.40$ & $0.9 \pm 0.40$ \\
L-carnitine + MSG high dose & $\mathrm{C}$ & $\mathrm{C}$ & $\mathrm{C}$ & $\mathrm{C}$ \\
ANOVA & $* *$ & $* *$ & $* *$ & $* *$ \\
\hline
\end{tabular}


Data are represented as mean of 10 samples $\pm \mathrm{SE}$

Means with the same letter for each parameter in the same column are not significantly different, otherwise they do (Duncan multiple range test).

$* * \mathrm{P}<0.01$ Highly Significant.

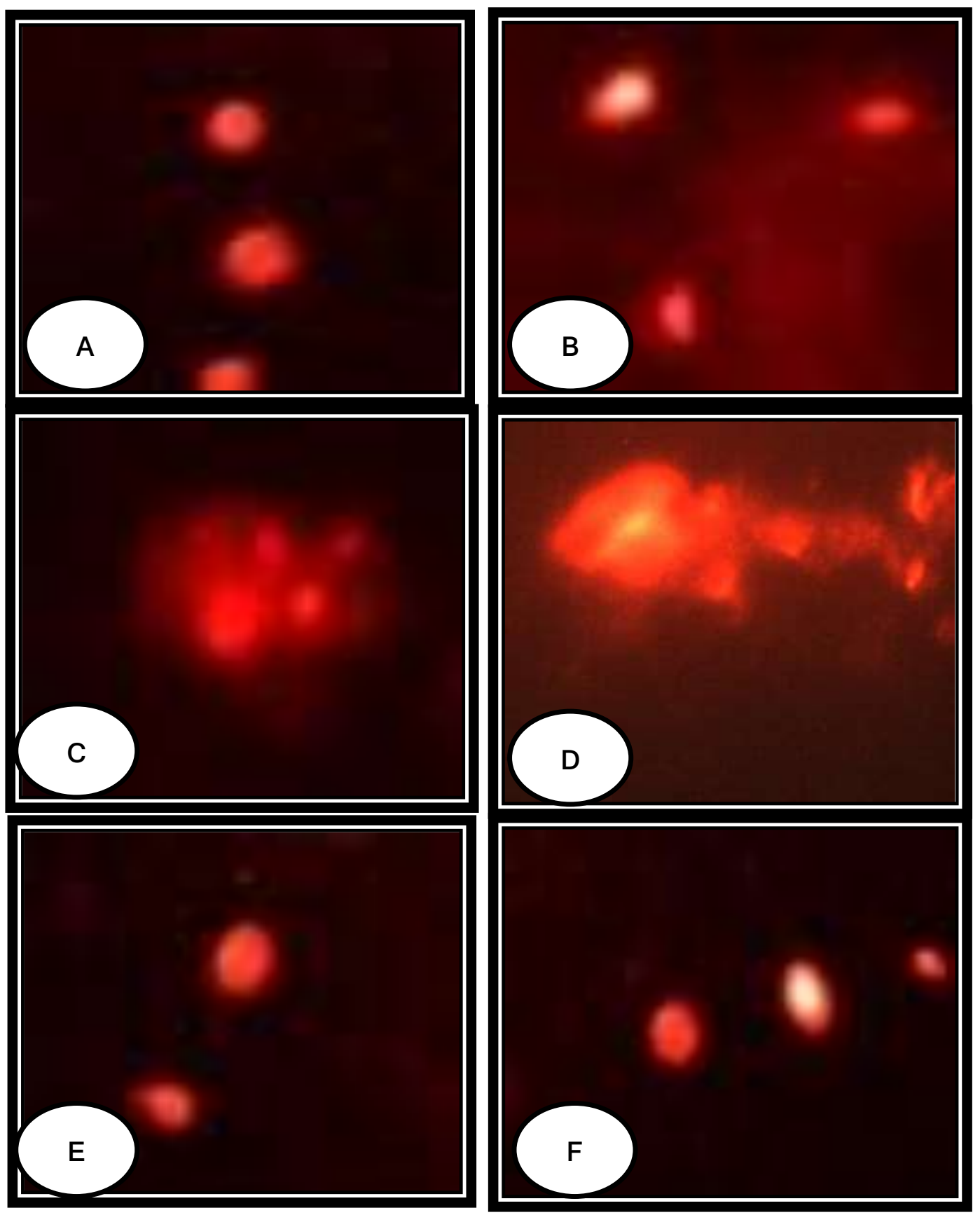

Figure 2: Photomicrographs of comet assay of testes of male albino mice showing DNA damage in treated groups with sublethal doses of MSG individually or co-administered with L- carnitine for 35 days. A control, B L-carnitine, C MSG low dose, D MSG high dose, E MSG low dose with L-carnitine and F MSG high dose and L-carnitine.

\section{DISCUSSION}

In the current study, mice treated with low and high doses of MSG showed a significant increase in their body weights in dose dependent manner compared with control and L- 
carnitine treated groups. Elevation of the body weight may be attributed to the metabolic changes caused by MSG. In such case all metabolic processes are probably reduced and the anabolic processes are accelerated leading to the body weight increase. These results are in line with the studies carried by Abd-El Aziz and Ashoush $\left({ }^{40}\right)$ who revealed that rats treated with MSG caused a significant increase in their body weight gain after 90 days. Also, Nosseir et al. $\left({ }^{41}\right)$ showed similar findings in rats after daily intraperitoneal injection with MSG (4 $\mathrm{ml} / \mathrm{kg}$ body weight) for 14 days. Likewise results of Yuan et al. $\left({ }^{42}\right)$ indicated that MSG could induced fat accumulation and obesity after intraperitonneal injection of male mice offspring by MSG ( $4 \mathrm{mg} / \mathrm{kg}$ body weight) from the first postnatal day until $14^{\text {th }}$ day (prepuberty), or to $28^{\text {th }}$ day (puberty), or day 56 (adult). In addition, oral administration of rats with $4 \mathrm{mg} / \mathrm{g}$ body weight for 2 or 4 weeks increased body weight of in both treated groups $\left({ }^{43}\right)$. Also, Elbassuoni et al. $\left({ }^{44}\right)$ found that MSG treatment increases the body weight in rats which given an oral dose of MSG $(35 \mathrm{mg} / \mathrm{kg} / \mathrm{d})$ for 2 weeks. In this respect, Bloom $\left({ }^{45}\right)$ suggested that MSG affects hypothalamus which is responsible for appetite, body temperature, water balance and sleep.

On the other hand, the present work showed that L-carnitine treatment resulted in reduction in the body weight gain of the treated mice. In this concern Pooyandjoo et al. $\left({ }^{46}\right)$ reported that L-carnitine supplementation shows a positive effect on body weight loss. Carnitine supplementing as weight-loss agent is based on the fact that regular oral ingestion of this drug leads to the increase of its intracellular concentration. This in-turn activates fat oxidation and helps reduction of the body's fat reserves and consequently, resulted in weight loss $\left({ }^{46}\right)$. However, the rat model presented by Brandsch and Eder $\left({ }^{47}\right)$ did not show a positive effect of L-carnitine supplementation on weight loss and body composition of rats fed an energydeficient diet.

In the present work, testes weight and gonadosomatic index of MSG treated mice showed significant reduction. This in agreement with the results of Nosseir et al. $\left({ }^{41}\right)$ who found that MSG cause reduction in testicular size and weight and Yuan et al. $\left({ }^{42}\right)$ who reported that testicular weight and volume decreased in all male offspring of mice interapertoneally injected with MSG (4 mg/kg body weight) from the first postnatal day (day 0), to day14 (prepuberty), or to day 28 (puberty) or till day 56 (adult). In the same line, daily oral administration of MSG (35, 350 and $3500 \mathrm{mg} / \mathrm{kg} \mathrm{BW} /$ day), for three months showed significant reduction in absolute testes weight $\left({ }^{40}\right)$. On the other hand, Alalwani $\left({ }^{48}\right)$ found that the relative testis weight increased in rats treated for 2 months with MSG at doses 30 \& $60 \mathrm{~g} / \mathrm{kg}$ body weight.

The results of the current study showed a zero reproductive index in MSG treated mice although the sperm count is more or less similar to the control group. Likewise, Hamza and 
El-Harbi $\left({ }^{49}\right)$ noticed significant decrease in the reproductive performance in male mice treated with MSG. Moreover, Hilwani et al. $\left({ }^{50}\right)$ revealed that intraperitoneal injections of MSG at 250, 500 and $1000 \mathrm{mg} / \mathrm{kg}$ of body weight for 14 days induced various implications on reproductive system of male mice which consequently affect fertility potential.

According to Parastie et al. $\left({ }^{51}\right)$ the sperm morphology must only be considered as an indicator of fertilization potential, not as an absolute indicator of sterility. The evaluation human sperm morphology and their clinical significance is still a controversial aspect of the semen analysis for determination of a male's fertility potential. Menkveld et al. $\left(^{52}\right)$ concluded that if the sperm morphology done correctly with strict application of guidelines outlined by WHO 2010, the sperm morphology measurement still has a very important role in clinical evaluation of male fertility potential. The toxic effect of MSG on testis caused a significant oligozoospermia and increased abnormal sperm morphology in dose-dependent fashion in male Wistar rat as shown by Onakewhor et al. $\left({ }^{8}\right)$.

Results of the present study revealed a significant increase in the abnormal sperm morphology and a significant decrease in the sperm motility in MSG treated animals compared with control and L-carnitine treated groups. Similar finding is reported by $\left({ }^{53}, 10\right)$ they studied the toxic effect of MSG on the sperm parameters and concluded a significant oligospermia and increase abnormal sperm morphology. In the same respect, significant decrease in sperm concentration, motility and live spermatozoa, in addition to the increased sperm abnormalities in male mice after oral administration of different doses of MSG for 90 days $\left({ }^{40}\right)$. In addition, the Hilwani et al. $\left({ }^{50}\right)$ recorded that decreased viability and integrity of sperm membrane of male mice intraperitoneally injected with MSG at 250, 500 and 1000 $\mathrm{mg} / \mathrm{kg}$ body weight for 14 days. Also, Dong and Robbins $\left({ }^{54}\right)$ reported in their review, a lower sperm counts in three of four studies and abnormal sperm morphology in five of six studies carried on MSG fed rats with $(0-4 \mathrm{~g} / \mathrm{kg})$ on duration of $10-56$ day. In the same concern, Kadir $\left({ }^{55}\right)$ found decreased in sperm motility and normal sperm morphology in rats received daily dose of MSG (1.53 or 3.07 or 6.13 or $12.27 \mathrm{~g} / \mathrm{kg}$ ) for 14 days. Furthermore, Ochiogu et al. $\left({ }^{56}\right)$ reported reduction in gonadotrophin-releasing hormone, luteinizing hormone, testosterone, which may causes reduction in epididymal sperm reserves after subcutaneous and oral administration of MSG at 0.25-1.00 g/ $\mathrm{kg}$ to albino rats for 6 weeks. In the same respect, rats treated intraperitoneally with monosodium glutamate ( $4 \mathrm{mg} / \mathrm{kg} \mathrm{b.w}$ ) for 14 days, showed reduction in all indices of sperm analysis as count, motility and viability $\left({ }^{57}\right)$. The data of the present study showed that co-administration of animals with MSG and 150 $\mathrm{mg} / \mathrm{kg}$ of L-carnitine revealed great improvement of all sperm parameters. In the same line, L-carnitine prevented, to a large extent harmful changes in sperm quality observed following exposure to different toxicants such gamma irradiation in mice $\left({ }^{28}\right)$ methotrexate-induced 
injury in rat testis $\left({ }^{58}\right)$ and cisplatin $\left({ }^{59}\right)$. They concluded that L-carnitine enhanced sperm count and motility and reduced sperm abnormalities. Moreover, rats treated with $500 \mathrm{mg} / \mathrm{kg}$ b.w. and intraperitoneally injected wit L-carnitine for 16 days improves the reproductive toxicity of cadmium as showed by increase in the number and viability of epididymal sperms $\left({ }^{60}\right)$. Also, Yaman and Topcu-Tarladacalisir $\left({ }^{61}\right)$ reported that, during the adult period, epididymal sperm count and viability were improved in rats treated with L-carnitine before prepubertal cisplatin injection. In the same respect, Khushboo et al. $\left({ }^{62}\right)$ found that oral administration 50 and $100 \mathrm{mg} / \mathrm{kg}$ L-carnitine into male albino rats for 30 days prevent deleterious effect on sperm quality after long-term copper consumption.

In fact, low levels of carnitine have been suggested as one of the contributing factors for sperm disorders such as azoospermia and asthenospermia $\left({ }^{63}\right)$. Similarly, many studies demonstrated that free carnitine levels in the epididymis affect the number, motility and maturity of spermatozoa in rat treated with cisplatin and sacrificed after $72 \mathrm{hrs}\left({ }^{64}\right)$. For instance, the spermatozoa make use of the energy provided by carnitine and acetyl carnitine in sperm metabolism which impacts positively on the overall spermatogenic process. Parallel with these results, it was reported by Adewoyin et al. $\left({ }^{65}\right)$ that sperm quality and function is enhanced with a regular intake of carnitine and acetyl carnitine.

In addition, a previous study from Banihani et al. $\left({ }^{66}\right)$ showed that a dosage of $0.5 \mathrm{mg} / \mathrm{mL}$ of L-carnitine significantly increased the motility of human spermatozoa after in vitro incubation and centrifugation. As concerning the metal chelator activity of L-carnitine, it has been shown that L-carnitine can effectively compete for the chelation of calcium ions. In fact, the detrimental effect of the high dosage of L-carnitine may be mainly due to its ability to bind $\mathrm{Ca}^{2+}$, a vital ion needed for sperm motion $\left({ }^{67}\right)$.

According to what has been said, it is clear that the use of L-carnitine and its esters, acetyl-Lcarnitine and propionyl-L-carnitine, is effective in determining an improvement in sperm parameters and in particular of the total motility and progressive motility, reduces the levels of ROS in seminal fluid, and would be able to improve the quality of the semen. The administration of these molecules in the treatment of male infertility (alone or in combination) is, therefore, a rational and effective therapeutic strategy. However, clinical benefits should not be achieved at high doses, since the evidence of calcium chelator activity of L-carnitine that may determine cell damage and decrease serum calcium $\left({ }^{68}\right)$.

Other antioxidant exhibited similar protective or ameliorative result against MSG induced testicular toxicity as those observed in our study such as vitamin $\mathrm{E}$ and selenium in male rats $\left({ }^{49}\right)$, ascorbic acid in male rats $\left({ }^{53,34,69}\right)$, curcumin in male rat $\left({ }^{70}\right)$. Al-Shahari and El-Kott $\left({ }^{71}\right)$ reported significant decrease in testis weight, sperm count and significant increase in their 
abnormality after MSG administration in $6 \mathrm{mg} / \mathrm{g} /$ day dissolved in distilled water for two months.

In comparison with other genotoxicity tests, the comet assay is sensitive for detecting low levels of DNA damage, the requirement for small numbers of cells, flexibility, low costs, simplicity of application, and short time needed to complete an experiment $\left({ }^{72}\right)$.

In vivo studies showed that MSG leads to oxidative damage and elevate lipid peroxidation rate $(73,74,75,53,76,77)$. Excess production or insufficient consumption of reactive oxygen derivatives results in oxidative stress, this also gives rise to DNA mutation, damage or fragmentation and DNA repair and/ or replication disorder following exposure to the reactive oxygen species (ROS) $\left({ }^{78}\right)$. In this manner, sperm DNA fragmentation tests have reopened the debate over their usefulness in improving pregnancy outcome. In this regards, two considerations should be disentangled. First, spermatozoa are not simply carriers of paternal chromosomes, but play a role beyond fertilization. For instance, the spermatozoon transcribes genes critical for early embryonic development, inferring that integrity of sperm genome is essential for a successful gestation. Second, if sperm factors play a role in early embryonic development, sperm DNA integrity tests are useful as diagnostic and prognostic markers, especially in the context of recurrent pregnancy loss $\left({ }^{79}\right)$.

In the current study, the MSG treatment at two sublethal doses, showed clear DNA degradation in the nuclei since the increasing in percentage of tail DNA is observed in comparison with the control and L-carnitine treated groups. These results coincided with the results of Ismail $\left({ }^{77}\right)$ when orally administered male rats with MSG $8 \mathrm{~g} / \mathrm{kg}$ for 90 days and found an increase in the tail moment in the testes cells of animals treated with MSG compared to the control group. Conversely, animals co-administered with L-carnitine and MSG displayed enhancement in DNA integrity. In the same manner, Lewis et al. $\left({ }^{80}\right)$ mentioned that carnitine may shield the spermatozoa from oxidative stress of DNA and membrane damage by reducing the reactive oxygen and reduces the detrimental effect of sperm lipid peroxidation. Carnitine has been shown to protect cells against mitochondrial and free radical-related nuclear DNA damage and improve mitochondrial functions by reducing stress mediated DNA damage through reducing the production of oxidants and enhancing antioxidant status $\left({ }^{19}\right)$. In this respect, carnitines act as safeguard to sperm and cell membrane against reactive oxygen species induced DNA fragmentation and apoptosis $\left({ }^{65}\right)$.

Acetyl L-carnitine protect cells against free radical induced nuclear DNA damage and improve mitochondrial functions by reducing stress-mediated DNA damage through reducing production of oxidants and enhancing antioxidant status $\left({ }^{81,82,19}\right)$. Several studies demonstrated that free carnitine levels in the epididymis affect the number, motility and maturity of spermatozoa $\left({ }^{83,22}\right)$. 


\section{CONCLUSION}

Hence it is recommended that the reproductive toxicity MSG in male albino mice could be ameliorated by L-carnitine supplementation. Furthermore, carry out other investigations using different parameters as antioxidants measurements and other immunohistochemical markers to evaluate the protective effects of different antioxidants against the reproductive toxicity of MSG. This study spots light organization of human health responsible for food safety to use common salt and natural products as flavor instead of MSG.

\section{REFERENCES}

1. Walker R, Lupien JR. The safety evaluation of monosodium glutamate. The Journal of nutrition. 2000 Apr 1;130(4):1049S-52S.

2. Niaz K, Zaplatic E, Spoor J. Extensive use of monosodium glutamate: A threat to public health?. EXCLI journal. 2018;17:273.

3. Solomon U, Gabriel OO, Henry EO, Adrian IO, Anthony TE. Effect of monosodium glutamate on behavioral phenotypes, biomarkers of oxidative stress in brain tissues and liver enzymes in mice. World J Neurosci. 2015;5:339-49.

4. Geha RS, Beiser A, Ren C, Patterson R, Greenberger PA, Grammer LC, Ditto AM, Harris KE, Shaughnessy MA, Yarnold PR, Corren J. Review of alleged reaction to monosodium glutamate and outcome of a multicenter double-blind placebo-controlled study. The Journal of nutrition. 2000 Apr 1;130(4):1058S-62S..

5. He K, Du S, Xun P, Sharma S, Wang H, Zhai F, Popkin B. Consumption of monosodium glutamate in relation to incidence of overweight in Chinese adults: China Health and Nutrition Survey (CHNS). The American journal of clinical nutrition. 2011 Apr 6;93(6):1328-36.

6. Araujo TR, Freitas IN, Vettorazzi JF, Batista TM, Santos-Silva JC, Bonfleur ML, Balbo SL, Boschero AC, Carneiro EM, Ribeiro RA. Benefits of L-alanine or Larginine supplementation against adiposity and glucose intolerance in monosodium glutamate-induced obesity. European journal of nutrition. 2017 Sep 1;56(6):2069-80. .

7. Tawfik MS, Al-Badr N. Adverse effects of monosodium glutamate on liver and kidney functions in adult rats and potential protective effect of vitamins $\mathrm{C}$ and $\mathrm{E}$. Food and Nutrition Sciences. 2012 May 16;3(05):651.

8. Onakewhor JU, Oforofuo IA, Singh SP. Chronic Administration of Monosodium Glutamate Induces Oligozoospermia and Glycoen Accumulation in Wistar Rat Testes. African Journal of Reproductive Health. 2017 Sep 19; 2(2). 
9. Oforofuo IA, Onakewhor JU, Idaewor PE. The effect of chronic administration of MSG on the histology of the adult Wistar rat testes. Bioscience Research Communications. 1997;9(2):30-56.

10. Igwebuike UM, Ochiogu IS, Ihedinihu BC, Ikokide JE, Idika IK. The effects of oral administration of monosodium glutamate (MSG) on the testicular morphology and cauda epididymal sperm reserves of young and adult male rats. Veterinarski Arhiv. 2011 Jul 20;81(4):525-34.

11. El-Sawy HB, Soliman MM, El-Shazly SA, Ali HA. Protective effects of camel milk and vitamin $\mathrm{E}$ against monosodium glutamate induced biochemical and testicular dysfunctions. Progress in Nutrition. 2018 Mar 29;20(1):76-85.

12. Talevi R, Barbato V, Fiorentino I, Braun S, Longobardi S, Gualtieri R. Protective effects of in vitro treatment with zinc, d-aspartate and coenzyme q10 on human sperm motility, lipid peroxidation and DNA fragmentation. Reproductive Biology and Endocrinology. 2013 Dec;11(1):81.

13. Jeulin C, Lewin LM. Role of free L-carnitine and acetyl-L-carnitine in post-gonadal maturation of mammalian spermatozoa. Human reproduction update. 1996 Mar $1 ; 2(2): 87-102$.

14. Peluso G, Nicolai R, Reda E, Benatti P, Barbarisi A, Calvani M. Cancer and anticancer therapy-induced modifications on metabolism mediated by carnitine system. Journal of cellular physiology. 2000 Mar;182(3):339-50.

15. Lenzi ALF, Sgrò P, Salacone P, Caponnecchia L, Dondero F. Use of carnitine therapy in selected cases of male factor infertility: a double blind cross over trial. Fertil Steril 2003; 79: 292-300.

16. Aleisa AM, Al-Majed AA, Al-Yahya AA, Al-Rejaie SS, Bakheet SA, Al-Shabanah OA, Sayed-Ahmed MM. Reversal of cisplatin-induced carnitine deficiency and energy starvation by propionyl-L-carnitine in rat kidney tissues. Clinical and Experimental Pharmacology and Physiology. 2007 Dec;34(12):1252-9.

17. Al-Majed AA. Carnitine deficiency provokes cisplatin-induced hepatotoxicity in rats. Basic \& clinical pharmacology \& toxicology. 2007 Mar;100(3):145-50.

18. İzgüt-Uysal VN, Ağaç A, Derin N. Effect of L-carnitine on carrageenan-induced inflammation in aged rats. Gerontology. 2003;49(5):287-92.

19. Cetinkaya A, Bulbuloglu E, Kantarceken B, Ciralik H, Kurutas EB, Buyukbese MA, Gumusalan Y. Effects of L-carnitine on oxidant/antioxidant status in acetic acidinduced colitis. Digestive diseases and sciences. 2006 Mar 1;51(3):488-94.

20. Dokmeci D, Inan M, Basaran UN, Yalcin O, Aydogdu N, Turan FN, Uz YH. Protective effect of L-carnitine on testicular ischaemia-reperfusion injury in rats. Cell 
Biochemistry and Function: Cellular biochemistry and its modulation by active agents or disease. 2007 Nov;25(6):611-8.

21. Sailo, L, Murthy MK., Pratima K, Roy VK, Gurusubramanian G, Monosodium Glutamate Toxicity and the Possible Protective Role of L-Carnitine. Science and Technology Journal Vol. 2018;( 6): 2321-3388.

22. NG CM, Blackman MR, Wang C, Swerdloff RS. The role of carnitine in the male reproductive system. Annals of the New York Academy of Sciences. 2004 Nov;1033(1):177-88.

23. Ruiz-Pesini E, Alvarez E, Enríquez JA, López-Pérez MJ. Association between seminal plasma carnitine and sperm mitochondrial enzymatic activities. International journal of andrology. 2001 Dec 31;24(6):335-40

24. Garcia CL, Filippi S, Mosesso P, Calvani M, Nicolai R, Mosconi L, Palitti F. The protective effect of L-carnitine in peripheral blood human lymphocytes exposed to oxidative agents. Mutagenesis. 2005 Nov 23;21(1):21-7.

25. Topcu-Tarladacalisir Y, Kanter M, Uzal MC. Role of L-carnitine in the prevention of seminiferous tubules damage induced by gamma radiation: a light and electron microscopic study. Archives of toxicology. 2009 Aug 1;83(8):735-46.

26. Abdelrazik H, Agarwal A. L-carnitine and assisted reproduction. Arch Med Sci. 2009 Mar 1;5:43-7.

27. Kanter M, Topcu-Tarladacalisir Y, Parlar S. Antiapoptotic effect of L-carnitine on testicular irradiation in rats. Journal of molecular histology. 2010 Apr 1;41(2-3):1218.

28. Ahmed MM, Ibrahim ZS, Alkafafy M, El-Shazly SA. L-carnitine protects against testicular dysfunction caused by gamma irradiation in mice. Acta histochemica. 2014 Jul 1;116(6):1046-55.

29. Salama AF, Kasem SM, Tousson E, Elsisy MK. Protective role of L-carnitine and vitamin $\mathrm{E}$ on the testis of atherosclerotic rats. Toxicology and industrial health. 2015 May;31(5):467-74.

30. Zare Z, Mohammadi M, Eimani H, Shafaroudi MM. Prevention of di (2-ethylhexyl) Phthalate-induced Testicular Disturbance in Mice by Co-administration of Lcarnitine. International journal of fertility \& sterility. 2011 Oct;5(3):186.

31. Okada FK, Stumpp T, Miraglia SM. Carnitine reduces testicular damage in rats treated with etoposide in the prepubertal phase. Cell and tissue research. 2009 Aug $1 ; 337(2): 269-80$.

32. Hafez ES. Rabbits. Reproduction and breeding techniques for laboratory animals. 1970:273-315. 
33. Predes FS, Monteiro JC, Paula TA, da Matta SL. Evaluation of rat testes treated with Arctium lappa L: Morphometric study. Brazilian Journal for Morphological Sciences. 2007.

34. Ekaluo UB, Erem FA, Omeje IS, Ikpeme EV, Ibiang YB, Ekanem BE. Aqueous leaf extract of guava: A non-toxic male fertility booster. IOSR J. Environ. Sci. Toxicol. Food Technol. 2013;3:33-5.

35. Björndahl L, Söderlund I, Kvist U. Evaluation of the one-step eosin-nigrosin staining technique for human sperm vitality assessment. Human reproduction. 2003 Apr $1 ; 18(4): 813-6$.

36. Ekaluo UB, Udokpoh AE, Ikpeme EV, Peter EU. Effect of chloroquine treatments on sperm count and weight of testes in male rats. Global Journal of Pure and Applied Sciences. 2008;14(2):175-7.

37. Ekaluo UB, Ikpeme EV, Udokpoh AE. Sperm head abnormality and mutagenic effects of aspirin, paracetamol and caffeine containing analgesics in rats. Int. J. Toxicol. 2009; 7:1-9..

38. Singh NP, McCoy MT, Tice RR, Schneider EL. A simple technique for quantitation of low levels of DNA damage in individual cells. Experimental cell research. 1988 Mar 1;175(1):184-91.

39. Dytham C. Choosing and Using Statistics: A Biologist's Guide. Black-well Science Ltd. London, UK OpenURL. 1999.

40. Abd-Elaziz AMS, and Ashoush IS. Effect of Monosodium Glutamate treatment on reproductive performance in Male Albino Rats. Egyptian J. of basic and applied physiology, 2007;6(1):101-110.

41. Nosseir NS, Ali MH, Ebaid HM. A histological and morphometric study of monosodium glutamate toxic effect on testicular structure and potentiality of recovery in adult albino rats. Res J Biol. 2012;2(2):66-78.

42. Yuan M, Huang G, Li J, Zhang J, Li F, Li K, Gao B, Zeng L, Shan W, Lin P, Huang L. Hyperleptinemia directly affects testicular maturation at different sexual stages in mice, and suppressor of cytokine signaling 3 is involved in this process. Reproductive Biology and Endocrinology. 2014 Dec;12(1):15.

43. El-Helbawy NF, Radwan DA, Salem MF, El-Sawaf ME. Effect of monosodium glutamate on body weight and the histological structure of the zona fasciculata of the adrenal cortex in young male albino rats. Tanta Medical Journal. 2017 Apr $1 ; 45(2): 104$. 
44. Elbassuoni EA, Ragy MM, Ahmed SM. Evidence of the protective effect of 1-arginine and vitamin D against monosodium glutamate-induced liver and kidney dysfunction in rats. Biomedicine \& Pharmacotherapy. 2018 Dec 1;108:799-808.

45. Bloom FE. Neurotransmission and the central nervous system. Goodman and Gilman's the pharmacological basis of therapeutics. 1996.

46. Pooyandjoo M, Nouhi M, Shab-Bidar S, Djafarian K, Olyaeemanesh A. The effect of (L-) carnitine on weight loss in adults: a systematic review and meta-analysis of randomized controlled trials. Obesity reviews. 2016 Oct;17(10):970-6.

47. Brandsch C, Eder K. Effect of L-carnitine on weight loss and body composition of rats fed a hypocaloric diet. Annals of nutrition and metabolism. 2002;46(5):205-10.

48. Alalwani AD. Monosodium glutamate induced testicular lesions in rats (histological study). Middle East Fertility Society Journal. 2014 Dec 1;19(4):274-80.

49. Hamza RZ, Al-Harbi MS. Monosodium glutamate induced testicular toxicity and the possible ameliorative role of vitamin E or selenium in male rats. Toxicology reports. 2014 Jan 1;1:1037-45.

50. Hilwani IN, Nasibah R, Nurdiana S, Norashirene MJ. Gonadotoxic and Cytotoxic Effect of Induced obesity via Monosodium Glutamate on Mus musculus Testis Cytoarchitecture and Sperm Parameter. International Journal of Agricultural and Biosystems Engineering. 2014 Aug 1;8(9):1000-3.

51. Parastie S, Romania T, Agostini DA. The importance of sperm morphology in the evaluation of male infertlity. Geneva. Diakses Maret. 2009.

52. Menkveld R, Holleboom CA, Rhemrev JP. Measurement and significance of sperm morphology. Asian journal of andrology. 2011 Jan;13(1):59.

53. Nayanatara A, Vinodini NA, Damodar G, Ahemed B, Ramaswamy CR, Shabarinath M, Bhat MR. Role of ascorbic acid in monosodium glutamate mediated effect on testicular weight, sperm morphology and sperm count, in rat testis. J Chin clin med. 2008 Jan;3(1):1-5.

54. Dong HV, Robbins WA. Ingestion of monosodium glutamate (MSG) in adult male rats reduces sperm count, testosterone, and disrupts testicular histology. Nutrition Bytes. 2015;19(1).

55. Kadir RE, Omotoso GO, Balogun TJ, Oyewopo AO. Effects of Monosodium Glutamate on Semen Quality and the Cytoarchitecture of the Testis of Adult Wistar Rats. International Journal of Biochemical and Health Sciences. 2011;7(1).

56. Ochiogu I, Ogwu D, Uchendu C, Okoye C, Ihedioha J, Mbegbu E. Effects of monosodium-L-glutamate administration on serum levels of reproductive hormones 
and cholesterol, epididymal sperm reserves and testicular histomorphology of male albino rats. Acta Veterinaria Hungarica. 2015 Feb 5;63(1):125-39.

57. Kianifard D. Epididymal sperm analysis following time and dose dependent administration of monosodium glutamate in preadolescent rats. Fertility and Sterility. 2016 Sep 1;106(3):e288.

58. YÜNCÜ M, BÜKÜCÜ N, Bayat N, Sencar L, TARAKÇIOĞLU M. The effect of vitamin $\mathrm{E}$ and L-carnitine against methotrexate-induced injury in rat testis. Turkish journal of medical sciences. 2015 Jun 19;45(3):517-25.

59. Eid AH, Abdelkader N F, Abd El-Raouf OM, Fawzy MH, El-Sayehb B M, and ElDenshary ES.: Protective effect of 1-carnitine against cisplatin-induced testicular toxicity in rats. J. Pharm Sci. Vol. March, 2016;(53):143.

60. Yari A, Asadi MH, Bahadoran H, Dashtnavard H, Imani H, Naghii MR. Cadmium toxicity in spermatogenesis and protective effects of L-carnitine in adult male rats. Biological trace element research. 2010 Nov 1;137(2):216-25.

61. Yaman O, Topcu-Tarladacalisir Y. L-carnitine counteracts prepubertal exposure to cisplatin induced impaired sperm in adult rats by preventing germ cell apoptosis. Biotechnic \& Histochemistry. 2018 Apr 3;93(3):157-67.

62. Khushboo M, Murthy MK, Devi MS, Sanjeev S, Ibrahim KS, Kumar NS, Roy VK, Gurusubramanian G. Testicular toxicity and sperm quality following copper exposure in Wistar albino rats: ameliorative potentials of L-carnitine. Environmental Science and Pollution Research. 2018 Jan 1;25(2):1837-62.

63. Agarwal A, Said TM. Carnitines and male infertility. Reproductive biomedicine online. 2004 Jan 1;8(4):376-84.

64. Coşkun N, Hatipoğlu MT, Özoğul C, Korkmaz C, Akyol SN, Mııılı SC, Arık GS, Erdoğan D. The protective effects of acetyl L-carnitine on testis gonadotoxicity induced by cisplatin in rats. Balkan medical journal. 2013 Jun;30(2):235.

65. Adewoyin M, Ibrahim M, Roszaman R, Isa M, Alewi N, Rafa A, Anuar M. Male infertility: the effect of natural antioxidants and phytocompounds on seminal oxidative stress. Diseases. 2017;5(1):9.

66. Banihani S, Sharma R, Bayachou M, Sabanegh E, Agarwal A. Human sperm DNA oxidation, motility and viability in the presence of l-carnitine during in vitro incubation and centrifugation. Andrologia. 2012 May;44:505-12.

67. Banihani SA, Bayachou M, Alzoubi K. L-carnitine is a calcium chelator: a reason for its useful and toxic effects in biological systems. Journal of basic and clinical physiology and pharmacology. 2015 Mar 1;26(2):141-5. 
68. Mongioi L, Calogero AE, Vicari E, Condorelli RA, Russo GI, Privitera S, Morgia G, La Vignera S. The role of carnitine in male infertility. Andrology. 2016 Sep;4(5):8007.

69. El-Maddah E I, Abo El-Noor MM, Abd El-Azeem MA. Ameliorative Effect of Vitamin $\mathrm{C}$ against Monosodium Glutamate Induced Toxicity on Testes and Cauda Epididymal Sperm Reserves in Adult Male Albino Rats. Ain Shams J Forensic Med Clin Toxicol, 2013; (20): 199-220.

70. Sakr SA, Badawy GM. Protective effect of curcumin on monosodium glutamateinduced reproductive toxicity in male albino rats. Glob J Pharmacol. 2013;7:416-22.

71. Al-Shahari EA, El-kott AF. Potential Effect of Grape Seeds Extract Against Monosodium Glutamate Induced Infertility in Rats. International Journal of Pharmacology. 2019 Jan 1;15(2):287-94.

72. Glei M, Schneider T, Schlörmann W. Comet assay: an essential tool in toxicological research. Archives of toxicology. 2016 Oct 1;90(10):2315-36.

73. Moreno G, Perelló M, Gaillard RC, Spinedi E. Orexin a stimulates hypothalamicpituitary-adrenal (HPA) axis function, but not food intake, in the absence of full hypothalamic NPY-ergic activity. Endocrine. 2005 Mar 1;26(2):99-106.

74. Farombi EO, Onyema OO. Monosodium glutamate-induced oxidative damage and genotoxicity in the rat: modulatory role of vitamin $\mathrm{C}$, vitamin $\mathrm{E}$ and quercetin. Human \& experimental toxicology. 2006 May;25(5):251-9.

75. Pavlovic V, Pavlovic D, Kocic G, Sokolovic D, Jevtovic-Stoimenov T, Cekic S, Velickovic D. Effect of monosodium glutamate on oxidative stress and apoptosis in rat thymus. Molecular and cellular biochemistry. 2007 Sep 1;303(1-2):161-6.

76. Vinodini N, Nayanatara AK, Gowda KM, Ahamed B, Ramaswamy C, Bhat RM. Effect of monosodium glutamate-induced oxidative damage on rat testis. J Chin Clin Med. 2008 Jan;3:370-3.

77. Ismail NH. Assessment of DNA damage in testes from young Wistar male rat treated with monosodium glutamate. Life Sci J. 2012;9(1):930-39.

78. Karaca S, Güder H. Dermatolojide Antioksidan Sistem/Antioxidant System in Dermatology. Turk Dermatoloji Dergisi. 2009 Jun 1;3(2):32.

79. Benagiano G, Paoli D, Lombardo F, Brosens JJ, Brosens IA. DNA fragmentation and the ultimate success of a pregnancy. Translational andrology and urology. 2017 Sep;6(Suppl 4):S539.

80. Lewis SE, Sterling ES, Young IS, Thompson W. Comparison of individual antioxidants of sperm and seminal plasma in fertile and infertile men. Fertility and sterility. 1997 Jan 1;67(1):142-7. 
81. Rani PJ, Panneerselvam C. Carnitine as a free radical scavenger in aging. Experimental gerontology. 2001 Nov 1;36(10):1713-26.

82. Calo LA, Pagnin E, Davis PA, Semplicini A, Nicolai R, Calvani M, Pessina AC. Antioxidant effect of L-carnitine and its short chain esters: relevance for the protection from oxidative stress related cardiovascular damage. International journal of cardiology. 2006 Feb 8;107(1):54-60.

83. Jeulin C, Lewin LM. Role of free L-carnitine and acetyl-L-carnitine in post-gonadal maturation of mammalian spermatozoa. Human reproduction update. 1996 Mar $1 ; 2(2): 87-102$.

\section{BJMHR is}

- Peer reviewed

- Monthly

- Rapid publication

- Submit your next manuscript at editor@bjmhr.com 